\title{
Kineococcus aurantiacus gen. nov., sp. nov., a New Aerobic, Gram-Positive, Motile Coccus with meso-Diaminopimelic Acid and Arabinogalactan in the Cell Wall
}

\author{
AKIRA YOKOTA,* TOMOHIKO TAMURA, TADASHI NISHII, AND TORU HASEGAWA \\ Institute for Fermentation, Osaka, Yodogawa-ku, Osaka 532, Japan
}

\begin{abstract}
A new aerobic, gram-positive, motile coccus isolated from soil is described. Strain $R A 333^{T}$ (T $=$ type strain) has the following characteristics: menaquinone MK-9 $\left(\mathrm{H}_{2}\right)$; $\mathrm{G}+\mathrm{C}$ content of DNA of 73.9 mol\%; mesodiaminopimelic acid, glutamic acid, and alanine in a molar ratio of ca. 1:1:2 (type A1 $\gamma$ ); and arabinose and galactose in the cell wall. The two sugars are contained in the cell wall as an arabinogalactan polymer. Mycolic acids are not present. The taxonomic characteristics of this organism are different from those of previously described aerobic, gram-positive cocci. The name Kineococcus aurantiacus gen. nov., sp. nov., is proposed. The type strain is strain RA 333, which has been deposited in the Institute for Fermentation, Osaka, as strain IFO 15268.
\end{abstract}

The following six genera of aerobic, gram-positive cocci have been described previously: Micrococcus (11), Deinococcus (2), Planococcus (11), Marinococcus (9), Sporosarcina (3), and Salinicoccus (23). Among the members of these genera, Planococcus, Marinococcus, and Sporosarcina species and some strains of Micrococcus agilis (12) are known to be motile.

During the course of our taxonomic study of motile actinomycetes isolated from natural sources, we found that a gram-positive coccus with a high DNA guanine-pluscytosine $(\mathrm{G}+\mathrm{C})$ content and meso-diaminopimelic acid (DAP) in its cell wall, which was isolated from soil in India, is motile and has taxonomic characteristics distinct from those of previously described aerobic, gram-positive cocci. In this paper, we describe the morphological, physiological, and chemotaxonomic characteristics of this isolate, strain RA $333^{\mathrm{T}},(\mathrm{T}=$ type strain $)$, and propose a new genus and species for this strain.

\section{MATERIALS AND METHODS}

Bacterial strains and culture conditions. Microorganisms exhibiting motility were screened by the dilution plate method on a medium containing $1.0 \%$ soluble starch, $0.1 \%$ casein, $0.05 \% \mathrm{~K}_{2} \mathrm{HPO}_{4}$, and $1.5 \%$ agar $(\mathrm{pH} 7.0$ to 7.5 ) supplemented with $25 \mu \mathrm{g}$ of nalidixic acid per $\mathrm{ml}, 12.5 \mu \mathrm{g}$ of kanamycin per ml, $5.0 \mu \mathrm{g}$ of cefsulodin per $\mathrm{ml}$, and $6.25 \mu \mathrm{g}$ of kabicidin per ml. Strain RA $333^{\mathrm{T}}$ was isolated from soil obtained from the Indore region of India. For chemotaxonomic studies this strain was grown in shake cultures $(10 \mathrm{~g}$ of yeast extract and $10 \mathrm{~g}$ of glucose in 1 liter of water; $\mathrm{pH} 7.0$ ) at $28^{\circ} \mathrm{C}$, harvested in the stationary phase, washed twice with water, and then freeze-dried. $M$. agilis IFO $15260^{\mathrm{T}}$ was used as a reference strain for the polar lipid study.

Morphological and cultural characteristics. Cell morphology was examined by using cells grown on yeast extract-malt extract agar ( $4 \mathrm{~g}$ of yeast extract, $10 \mathrm{~g}$ of malt extract, $4 \mathrm{~g}$ of D-glucose, and $15 \mathrm{~g}$ of agar; $\mathrm{pH} 7.3$ ). The sample used for scanning electron microscopy with a model JSM 5400 scanning electron microscope (JEOL, Ltd., Tokyo, Japan) was prepared by dehydrating cells through a graded ethanol

\footnotetext{
* Corresponding author.
}

series and then in a Hitachi model HCP-2 critical point drying apparatus. Motility was observed under a light microscope by using cells in the logarithmic growth phase grown on yeast extract-malt extract agar or cells in the stationary phase after incubation at $28^{\circ} \mathrm{C}$ for $1 \mathrm{~h}$ in $0.01 \mathrm{M}$ phosphate buffer ( $\mathrm{pH} 7.0$ ) containing 10\% soil extract. Flagellation was observed with a model JEM-1200EX transmission electron microscope (JEOL) after shadowing with platinum-palladium.

Phenotypic characterization. Unless indicated otherwise, all tests were carried out at $28^{\circ} \mathrm{C}$. Catalase activity was determined by bubbling in a $3 \%$ hydrogen peroxide solution. Oxidase activity was determined by the oxidation of $1 \%$ tetramethyl- $p$-phenylenediamine on filter paper. Acid production from carbohydrates was studied in media containing $0.5 \%$ peptone, $0.25 \% \mathrm{NaCl}, 0.003 \%$ bromcresol purple, and each carbohydrate at a concentration of $0.5 \%(\mathrm{pH} 7.2)$. Nitrate reduction and hydrolysis of starch, gelatin, casein, and esculin were tested by the methods described by Cowan and Steel (6). Susceptibility to antibiotics and antimicrobial agents was examined by placing antibiotic disks (diameter, 8 mm; Showa Yakuhin Kako Co., Ltd., Tokyo, Japan) on yeast extract-malt extract agar plates seeded with a suspension of the strain. Plates were incubated at $28^{\circ} \mathrm{C}$ for 3 days, and the diameters of inhibition zones were measured.

Peptidoglycan analysis. Cell walls were prepared from ca. $500 \mathrm{mg}$ of dry cells by mechanical disruption with an ultrasonic oscillator and were purified as described by Schleifer and Kandler (19). The amino acid composition of complete wall hydrolysates was determined with a model LC6AD high-performance liquid chromatography (HPLC) apparatus (Shimadzu Co., Ltd., Kyoto, Japan) equipped with a Wakopak WS-PTC column (Wako Pure Chemical Industries, Ltd., Osaka, Japan) as phenyl thiocarbamoyl (PTC) derivatives according to the manufacturer's instructions (24). The amino acid composition and isomers of DAP were determined by developing preparations on cellulose thin-layer chromatography plates (Tokyo Kasei Co., Ltd., Tokyo, Japan), using two-dimensional descending chromatography as described by Harper and Davis (10).

Cell wall sugar analysis. Cell walls were hydrolyzed with 2 $\mathrm{N} \mathrm{HCl}$ at $100^{\circ} \mathrm{C}$ for $2 \mathrm{~h}$, dried in vacuo, and then analyzed by the method of Mikami and Ishida (14), using a model LC-5A 


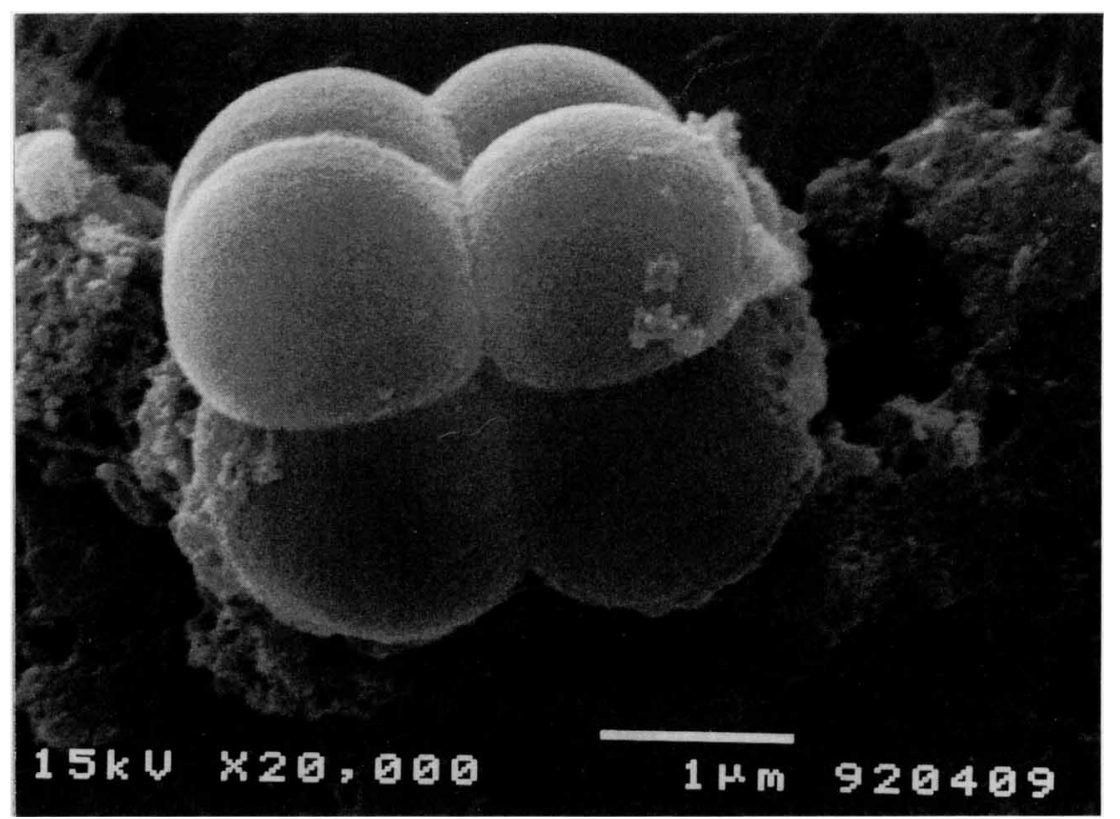

FIG. 1. Scanning electron micrograph of strain RA $333^{\mathrm{T}}$ cells grown on yeast extract-malt extract agar.

HPLC apparatus (Shimadzu) equipped with a Shim-pack ISA 07/S2504 column ( 250 by $4 \mathrm{~mm})$ and a Shimadzu model RE-530 spectrofluorometer.

Isolation of cell wall polysaccharide. Cell wall polysaccha- ride was prepared by the method described previously (21). Briefly, a cell wall preparation was suspended in $0.5 \mathrm{~N}$ $\mathrm{NaOH}$ and heated at $90^{\circ} \mathrm{C}$ for $16 \mathrm{~h}$. The suspension was neutralized with acetic acid and centrifuged, and the po-

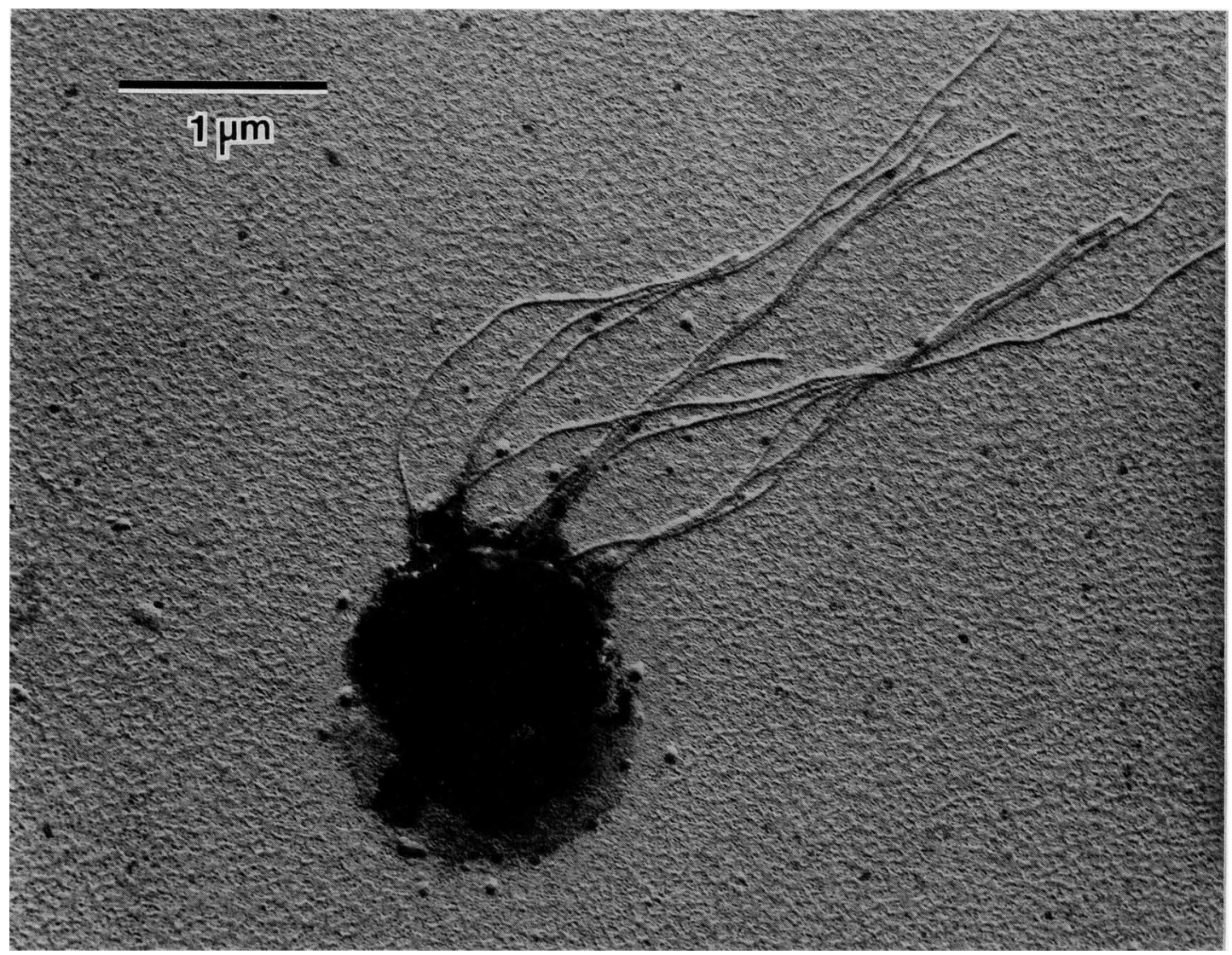

FIG. 2. Transmission electron micrograph of a motile cell of strain RA $333^{\mathrm{T}}$. 
TABLE 1. Differential characteristics of strain RA $333^{\mathrm{T}}$, aerobic gram-positive cocci, and related taxa ${ }^{a}$

\begin{tabular}{|c|c|c|c|c|c|c|c|c|c|c|c|}
\hline Taxon & $\begin{array}{c}\text { Cell } \\
\text { morph- } \\
\text { ology }\end{array}$ & $\begin{array}{l}\text { Motil- } \\
\text { ity }\end{array}$ & $\begin{array}{l}\text { Endo- } \\
\text { spores }\end{array}$ & $\begin{array}{c}\mathrm{G}+\mathrm{C} \\
\text { content } \\
(\mathrm{mol} \%)\end{array}$ & $\begin{array}{l}\text { Diamino } \\
\text { acid }\end{array}$ & $\underset{\text { type }^{b}}{\text { Murein }}$ & $\begin{array}{l}\text { Mycolic } \\
\text { acid }\end{array}$ & $\begin{array}{l}\text { Glycol- } \\
\text { ate test }\end{array}$ & $\begin{array}{l}\text { Cell wall } \\
\text { sugar }\end{array}$ & $\begin{array}{l}\text { Menaquinone } \\
\text { system }\end{array}$ & $\begin{array}{l}\text { Cellular fatty } \\
\text { acid(s) }\end{array}$ \\
\hline Isolate RA $333^{\mathrm{T}}$ & Coccus & + & - & 73.9 & meso-DAP & $\mathrm{Al} \gamma$ & - & Ace & Ara, Gal & MK- $9\left(\mathrm{H}_{2}\right)$ & anteiso-15:0 \\
\hline Micrococcus & Coccus & $-1+^{c}$ & - & $65-75$ & L-Lys & $\begin{array}{l}\mathrm{A} 4 \alpha \\
\mathrm{A} 3 \alpha\end{array}$ & - & Ace & $\mathrm{NC}$ & 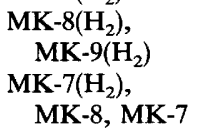 & anteiso-15:0 \\
\hline Deinococcus & Coccus & - & - & $62-71$ & $\begin{array}{l}\text { L-Orn } \\
\text { L-Lys }\end{array}$ & $\begin{array}{l}\mathrm{A} 3 \beta \\
\mathrm{A} 3 \alpha\end{array}$ & - & ND & $\mathrm{NC}$ & MK-8 & $\begin{array}{l}16: 0 \\
16: 1\end{array}$ \\
\hline Planococcus & Coccus & + & - & $39-52$ & L-Lys & $\mathrm{A} 3 \alpha$ & - & ND & $\mathrm{NC}$ & MK-8, MK-7 & $\begin{array}{l}\text { anteiso-15:0 } \\
\text { anteiso-17:0 }\end{array}$ \\
\hline Sporosarcina & Coccus & + & + & $40-42$ & $\begin{array}{l}\text { L-Lys } \\
\text { L-Orn }\end{array}$ & $\begin{array}{l}\mathrm{A} 4 \alpha \\
\mathrm{A} 4 \beta\end{array}$ & - & ND & $\mathrm{NC}$ & MK-7 & ND \\
\hline Marinococcus & Coccus & + & - & $44-47$ & meso-DAP & Al $\gamma$ & - & ND & $\mathrm{NC}$ & MK-7, MK-6 & $\begin{array}{l}\text { anteiso-15:0 } \\
\text { anteiso-17:0 }\end{array}$ \\
\hline Salinicoccus & Coccus & - & - & 51.2 & L-Lys & $\mathrm{A} 4 \alpha$ & - & ND & ND & None & $\begin{array}{l}\text { anteiso-15:0, } \\
\text { iso-15:0 }\end{array}$ \\
\hline Corynebacterium & Rod & - & - & $51-65$ & meso-DAP & $\mathrm{Al} \gamma$ & + & Ace & Ara, Gal & 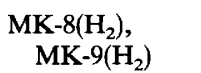 & $16: 0,18: 1$ \\
\hline C. amycolata & Rod & - & - & 61 & meso-DAP & $\mathrm{Al} \gamma$ & - & Ace & Ara, Gal & 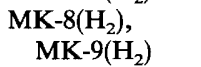 & $16: 0,18: 1$ \\
\hline Rhodococcus & Rod & - & - & $60-69$ & meso-DAP & $\mathrm{A} 1 \gamma$ & + & Gly & Ara, Gal & MK- $8\left(\mathrm{H}_{2}\right)$ & $16: 0,18: 1$ \\
\hline Tsukamurella & Rod & - & - & $66-73$ & meso-DAP & $\mathrm{A} 1 \gamma$ & + & & Ara, Gal & MK-9 & $16: 0,18: 1$ \\
\hline Arthrobacter & Rod & - & - & $59-66$ & L-Lys & $\mathrm{A} 3 \alpha$ & - & Ace & $\mathrm{NC}$ & MK-9( $\left.\mathrm{H}_{2}\right)$ & $\begin{array}{l}\text { anteiso-15:0, } \\
\text { anteiso-17:0 }\end{array}$ \\
\hline & & & & & & $\mathrm{A} 4 \alpha$ & & & & MK-8,MK-9 & \\
\hline
\end{tabular}

${ }^{a}$ Data from references 2 through 5, 8, 9, 11, 18, and 23. Abbreviations: L-Lys, L-lysine; L-Orn, L-ornithine; Ace, acetyl residues; Gly, glycolyl residues; Ara, arabinose; Gal, galactose; ND, not determined; NC, not characteristic.

${ }^{b}$ Designations for murein types are the designations of Schleifer and Kandler (19).

${ }^{c}-1+$, absent except for one species (M. agilis).

Hysaccharide in the supernatant was purified by chromatography performed with a DEAE-Toyopearl column. Sugar composition was determined by HPLC as described above.

Glycolyl analysis. Glycolyl testing was carried out by using the method of Uchida and Aida (22).

Analysis of cellular fatty acids. Fatty acids were extracted from dry cells $(50 \mathrm{mg})$ by acid methanolysis and were examined by using a model GC-9A gas-liquid chromatography apparatus (Shimadzu) equipped with a glass column $(5 \mathrm{~m}$ by $0.28 \mathrm{~cm}$ ) containing $10 \%$ diethyleneglycol succinate on Chromosorb $\mathrm{W}$ at $180^{\circ} \mathrm{C}(20)$.

Analysis of polar lipids. Free lipids were extracted from dry cells $(100 \mathrm{mg})$, purified by the method of Minnikin et al. (16), and examined by two-dimensional thin-layer chromatography, using Kieselgel $60 \mathrm{~F}_{254}$ plates. Lipids were visualized by spraying the plates with $10 \%$ molybdophosphoric acid in ethanol, followed by heating at $140^{\circ} \mathrm{C}$ for $10 \mathrm{~min}$. Specific spray reagents for lipid phosphate, $\alpha$-naphthol (for sugar), and ninhydrin (for amino groups) were also used.

Analysis of mycolic acids. Mycolic acids were analyzed by using the method of Minnikin et al. (15).

Analysis of isoprenoid quinones. Menaquinones were extracted from dry cells $(200 \mathrm{mg})$ with chloroform-methanol $(2: 1, \mathrm{vol} / \mathrm{vol})$ and were purified by thin-layer chromatography, using benzene as the solvent. The menaquinones were extracted with diethyl ether, dried by using a nitrogen stream, and then analyzed by HPLC, using a Shimadzu model LC-5A apparatus equipped with a Zorbax octyldecyl silane column ( 4.6 by $150 \mathrm{~mm}$ ).

DNA base composition. DNA was obtained by the method of Saito and Miura (17). The G+C content of the DNA was determined by the method of Mesbah et al. (13) after treatment with P1 nuclease and alkaline phosphatase and by
HPLC, using a model LC-6AD apparatus (Shimadzu) equipped with a Comosil $5 \mathrm{C}_{18}$-AR column $(4.6$ by $150 \mathrm{~mm}$; Nacalai Tesque, Inc., Tokyo, Japan).

\section{RESULTS AND DISCUSSION}

Morphological, physiological, and biochemical characteristics. Isolate RA $333^{\mathrm{T}}$ is a gram-positive coccus. The cells are 1.0 to $1.5 \mu \mathrm{m}$ in diameter and occur in clusters, as well as in pairs, tetrads, and octads (Fig. 1). Rod-shaped or filamentous cells were not observed at any stage of growth or when the organism was cultured under different growth conditions. On most solid media the strain formed rough, round, convex, orange colonies. Cells in the early phase grown on yeast extract-malt extract agar were motile at a low frequency. Cells in the stationary phase formed clusters and were not motile. However, after incubation at $28^{\circ} \mathrm{C}$ for few hours in $0.01 \mathrm{M}$ phosphate buffer ( $\mathrm{pH} 7.0$ ) containing $10 \%$ soil extract, almost all of the cells were actively motile. Motile cells had tufts of flagella, as shown in Fig. 2. Cells grown under all conditions were surrounded by a slime- or capsular polysaccharide-like substance (Fig. 1), which seemed to prohibit motility of the cells. However, when the cells were incubated under the conditions described above, almost all of the cells were motile. The fiagella shown in Fig. 2 appeared to be thick lines, which might have been due to the deposit of polysaccharide-like substance on the surface.

The biochemical characteristics of strain RA $333^{\mathrm{T}}$ are summarized in Table 2. This strain had catalase and urease activities but not oxidase activity. It did not hydrolyze esculin and weakly utilized propionate; it was strictly aerobic. The temperature range for growth was 9 to $36^{\circ} \mathrm{C}$, and the optimum temperature was $28^{\circ} \mathrm{C}$. The $\mathrm{pH}$ range for growth 
TABLE 2. Phenotypic characteristics of strain RA $333^{\mathrm{T}}$

\begin{tabular}{|c|c|}
\hline Characteristic & Strain RA $333^{\mathrm{T}}$ \\
\hline \multicolumn{2}{|c|}{ 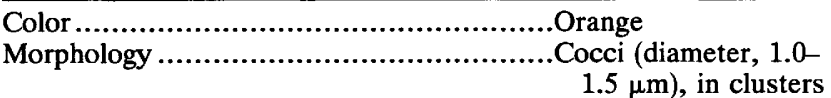 } \\
\hline \multicolumn{2}{|c|}{ Gram staining..................................... } \\
\hline \multicolumn{2}{|l|}{ Motility ............................................... } \\
\hline \multicolumn{2}{|l|}{ Spore formation } \\
\hline \multicolumn{2}{|l|}{ Oxidase } \\
\hline \multicolumn{2}{|l|}{ Catalase } \\
\hline \multicolumn{2}{|l|}{ Urease ............................................. } \\
\hline \multicolumn{2}{|l|}{ Nitrate reduction .....................................- } \\
\hline \multicolumn{2}{|l|}{ Hydrolysis of: } \\
\hline \multicolumn{2}{|l|}{ Gelatin } \\
\hline \multicolumn{2}{|l|}{ Casein } \\
\hline \multicolumn{2}{|l|}{ Esculin .............................................- } \\
\hline \multicolumn{2}{|l|}{ 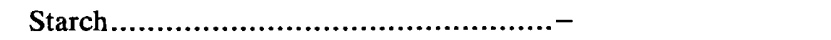 } \\
\hline \multicolumn{2}{|l|}{ Utilization of propionate $\ldots \ldots \ldots \ldots \ldots \ldots \ldots \ldots \ldots+$} \\
\hline \multicolumn{2}{|l|}{ Acid production from: } \\
\hline \multicolumn{2}{|l|}{ 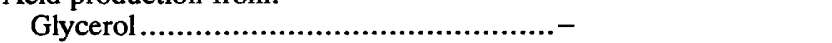 } \\
\hline \multicolumn{2}{|l|}{ D-Xylose ......................................... } \\
\hline \multicolumn{2}{|l|}{ D-Ribose .......................................- } \\
\hline \multicolumn{2}{|l|}{ L-Arabinose ..................................... } \\
\hline \multicolumn{2}{|l|}{ 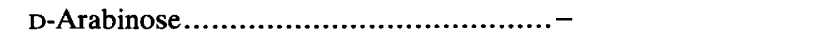 } \\
\hline \multicolumn{2}{|l|}{ D-Glucose............................................ } \\
\hline \multicolumn{2}{|l|}{ D-Mannose ........................................- } \\
\hline \multicolumn{2}{|l|}{ D-Galactose ................................... - } \\
\hline \multicolumn{2}{|l|}{ D-Fructose................................................. } \\
\hline \multicolumn{2}{|l|}{ L-Rhamnose } \\
\hline \multicolumn{2}{|l|}{ Mannitol .................................................- } \\
\hline \multicolumn{2}{|l|}{ 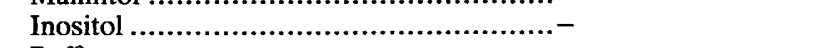 } \\
\hline \multicolumn{2}{|l|}{ Raffinose ........................................... } \\
\hline \multicolumn{2}{|l|}{ Maltose............................................- } \\
\hline 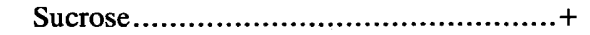 & \\
\hline Trehalose ...............................................- & \\
\hline 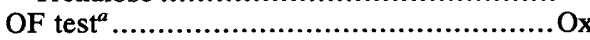 & idation \\
\hline Temp range for growth $\left({ }^{\circ} \mathrm{C}\right)$ & \\
\hline 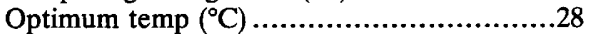 & \\
\hline 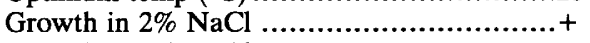 & \\
\hline Growth in $5 \% \mathrm{NaCl}$ & \\
\hline 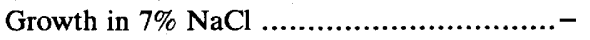 & \\
\hline Anaerobic growth .................................- & \\
\hline
\end{tabular}

${ }^{a} \mathrm{OF}$, Oxidation-fermentation. was $\mathrm{pH} 6.0$ to 9.0 . The strain was resistant to sulbenicillin, cefsulodin, colistin, polymixin B, and fosfomycin but was susceptible to cefem and tetracycline antibiotics.

Chemotaxonomic characteristics. The chemotaxonomic characteristics of strain RA $333^{\mathrm{T}}$ are summarized in Table 3. The quinone was hydrogenated menaquinone $\mathrm{MK}-9\left(\mathrm{H}_{2}\right)$. The amino acids in the cell wall were meso-DAP, alanine, and glutamic acid (molar ratio, ca. 1:2:1); this corresponds to murein type A1 $\gamma$ of Schleifer and Kandler (19). The only cell wall sugars that were detected were arabinose and galactose. An examination of the polysaccharide isolated from the cell wall indicated that these two sugars were present as an arabinogalactan polymer in the cell wall (molar ratio of galactose to arabinose, ca. 1.00:1.10). Mycolic acids were not present. The glycan moiety of the murein contained only acetyl residues. The major cellular fatty acid of RA $333^{\mathrm{T}}$ was 12-methyltetradecanoic (anteiso- $\mathrm{C}_{15: 0}$ ) acid (88.7\%). The strain had the polar lipid pattern shown in Fig. 3A. Diphosphatidylglycerol and phosphatidylglycerol were identified by their chromatographic behavior and staining characteristics. In addition, unknown glycolipids were present. Thus, the polar lipid pattern of strain RA $333^{\mathrm{T}}$ distinguishes this organism from Micrococcus species (Fig. 3B).

The following four genera of aerobic, gram-positive, motile cocci have been described previously: Planococcus, Marinococcus, Micrococcus, and Sporosarcina. Chemotaxonomy has proved to be very useful in providing characteristics that distinguish these taxa from neighboring taxa. Strain RA $333^{\mathrm{T}}$ can be distinguished readily from all of these taxa on the basis of chemical characteristics (Table 1). The menaquinone and cellular fatty acid compositions, the $\mathrm{G}+\mathrm{C}$ content of the DNA, and the presence of motility in strain RA $333^{\mathrm{T}}$ most closely resemble the characteristics of $M$. agilis (12). However, these organisms are different, as $M$. agilis contains type $\mathrm{A} 4 \alpha$ peptidoglycan, has no characteristic sugars in its cell wall, and produces a different polar lipid pattern (Fig. 3B). Thus, the combination of the presence of meso-DAP and arabinogalactan in the cell wall, a $\mathrm{G}+\mathrm{C}$ content of $73.9 \mathrm{~mol} \%$, and the presence of $\mathrm{MK}-9\left(\mathrm{H}_{2}\right)$ readily

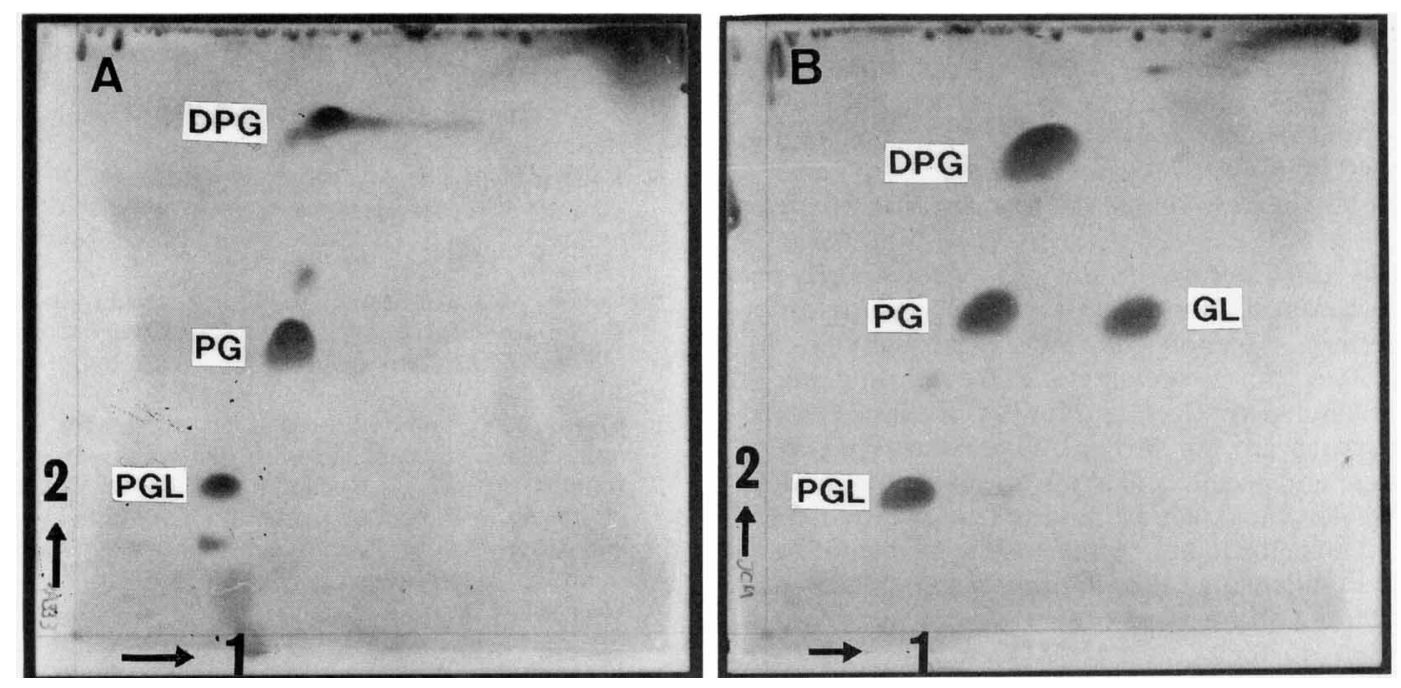

FIG. 3. Two-dimensional thin-layer chromatograms of the polar lipids of strain RA $333^{\mathrm{T}}$ (A) and $M$. agilis IFO $15260^{\mathrm{T}}$ (B). Chloroformmethanol-water $(65: 25: 4, \mathrm{vol} / \mathrm{vol} / \mathrm{vol})$ was used in the first dimension, and chloroform-methanol-acetic acid-water $(80: 12: 15: 4, \mathrm{vol} / \mathrm{vol} / \mathrm{vol} / \mathrm{vol})$ was used in the second dimension. Lipids were visualized by spraying the plates with $10 \%$ molybdophosphoric acid in ethanol, followed by heating at $150^{\circ} \mathrm{C}$ for $10 \mathrm{~min}$. Abbreviations: DPG, diphosphatidylglycerol; PG, phosphatidylglycerol; PGL, unidentified phosphoglycolipid; GL, unidentified glycolipid. 
TABLE 3. Chemotaxonomic characteristics of strain RA $333^{\mathrm{T}}$

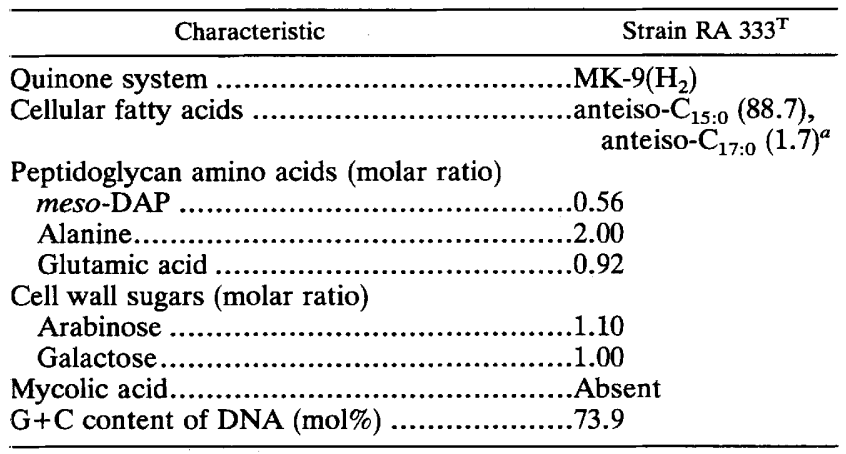

a The values in parentheses are the percentages of the total fatty acids.

distinguishes strain RA $333^{\mathbf{T}}$ from all previously described aerobic, gram-positive cocci (Table 3 ). The presence of MK- $9\left(\mathrm{H}_{2}\right)$, acetyl residues in the murein, and meso-DAP and arabinogalactan in the cell wall is consistent with organisms classified in the mycolic acid-containing taxa, such as the genera Corynebacterium, Mycobacterium, Tsukamurella, and Rhodococcus, but the absence of mycolic acids and the occurrence of branched fatty acids, together with cell morphology, clearly distinguish our isolate from all of these taxa. The mycolic acid-lacking coryneform bacterium Corynebacterium amycolata (4) has chemotaxonomic characteristics similar to those of our strain, but the two organisms can be differentiated on the basis of cellular fatty acid composition, cell morphology, and motility.

Thus, on the basis of biochemical and chemical criteria, our new isolate can be distinguished readily from all previously described aerobic, gram-positive cocci and in our opinion warrants a new taxon. Therefore, we formally propose that strain RA $333^{\mathrm{T}}$ should be classified in a new genus, Kineococcus, as Kineococcus aurantiacus gen. nov., sp. nov.

Much additional work, including DNA-rRNA hybridization studies and comparative analysis of the 16S rRNA sequences of Kineococcus strains and other gram-positive, aerobic cocci and rods, will be necessary to determine the relationship of this new genus to previously described grampositive bacteria. Meanwhile, the genus Kineococcus should be considered one of the several genera belonging to the recently proposed family Pseudonocardiaceae $(1,7)$.

Descriptions for the new genus and new species are given below.

Description of Kineococcus gen. nov. Kineococcus (Ki.ne. o.coc'cus. Gr. n. kinesis, motion; Gr. n. coccus, a grain or berry; M.L. fem. n. Kineococcus, motile coccus) cells are spherical and 1.0 to $1.5 \mu \mathrm{m}$ in diameter and occur in pairs, in thetrads, or in clusters. Motile. The motile cells have tufts of flagella. Endospores are not formed. Gram positive. Colonies are circular and rough and may be cream colored to orange. Strictly aerobic. Catalase and urease positive. Oxidase negative. The cells do not reduce nitrate to nitrite. Acid is produced from glucose and some other sugars. Esculin is hydrolyzed. Starch, gelatin, and casein are not hydrolyzed. The optimum growth temperature is $27^{\circ} \mathrm{C}$.

The cell wall peptidoglycan contains meso-DAP, alanine, and glutamic acid. The major menaquinone is MK- $\left(\mathrm{H}_{2}\right)$. Mycolic acid is not present. The major cellular fatty acid is anteiso- $\mathrm{C}_{15: 0}$. Diphosphatidylglycerol, phosphatidylglycerol, and unidentified glycolipids are present as polar lipids.
The type species is Kineococcus aurantiacus.

Description of Kineococcus aurantiacus sp. nov. Kineococcus aurantiacus (au.ran.ti'a.cus. M. L. n. aurantium, generic name of orange; M. L. adj. aurantiacus, orange colored) cells are spherical and 1.0 to $1.5 \mu \mathrm{m}$ in diameter and occur in pairs, in tetrads, or in clusters. Motile. The motile cells have tufts of flagella. Endospores are not formed. Gram positive. Colonies are circular and rough and may be cream colored to orange. Strictly aerobic. Catalase and urease positive. Oxidase negative. The cells do not reduce nitrate to nitrite. Acid is produced from D-glucose, D-xylose, D-fructose, sucrose, and L-arabinose. Acid is not produced from glycerol, D-ribose, D-arabinose, raffinose, maltose, D-galactose, D-mannose, inositol, L-rhamnose, mannitol, or trehalose. Esculin, starch, gelatin, and casein are not hydrolyzed. The optimum growth temperature is $28^{\circ} \mathrm{C}$.

Chemical characteristics, such as amino acid composition of the cell wall peptidoglycan, menaquinone system, mycolic acids, cellular fatty acids, and polar lipids, are the same as the chemical characteristics described above for the genus. The DNA base composition of the type strain is $73.9 \mathrm{~mol} \%$, as determined by HPLC. Distribution: soil.

The type strain is strain RA 333 which has been deposited in the Institute for Fermentation, Osaka, as strain IFO 15268.

\section{ACKNOWLEDGMENTS}

We thank Akio Shino and Kenji Hikawa, Research and Development Division, Takeda Chemical Industries, Ltd., for help with electron microscopy. We also thank Mariko Takeuchi of the Institute for Fermentation, Osaka, for the analysis of cell wall polysaccharide.

\section{REFERENCES}

1. Bowen, T., E. Stackebrandt, M. Dorsch, and T. M. Embley. 1989. The phylogeny of Amycolata autotrophica, Kibdelosporangium aridum and Saccharothrix australiensis. J. Gen. Microbiol. 135:2529-2536.

2. Brooks, B. W., and R. G. E. Murray. 1981. Nomenclature for "Micrococcus radiodurans" and other radiation-resistant cocci: Deinococcaceae fam. nov. and Deinococcus gen. nov., including five species. Int. J. Syst. Bacteriol. 31:353-360.

3. Claus, D., and F. Fahmy. 1986. Genus Sporosarcina Kluyver and van Niel 1936, 401 AL, p. 1202-1206. In P. H. A. Sneath, N. S. Mair, M. E. Sharpe, and J. G. Holt (ed.), Bergey's manual of systematic bacteriology, vol. 2. The Williams \& Wilkins Co., Baltimore.

4. Collins, M. D., R. A. Burton, and D. Jones. 1988. Corynebacterium amycolatum $\mathbf{s p . ~ n o v . , ~ a ~ n e w ~ m y c o l i c ~ a c i d - l e s s ~ C o r y n e b a c - ~}$ terium species from human skin. FEMS Microbiol. Lett. 49: 349-352.

5. Collins, M. D., J. Smida, M. Dorsch, and E. Stackebrandt. 1988. Tsukamurella gen. nov. harboring Corynebacterium paurometabolum and Rhodococcus aurantiacus. Int. J. Syst. Bacteriol. 38:385-391.

6. Cowan, S. T., and K. J. Steel. 1965. Manual for the identification of medical bacteria. Cambridge University Press, London.

7. Embley, M. T., J. Smida, and E. Stackebrandt. 1988. The phylogeny of mycolate-less wall chemotype IV actinomycetes and description of Pseudonocardiaceae fam. nov. Syst. Appl. Microbiol. 11:44-52.

8. Goodfellow, M. 1986. Genus Rhodococcus Zopf $1891,28^{\mathrm{AL}}$, p. 1472-1481. In P. H. A. Sneath, N. S. Mair, M. E. Sharpe, and J. G. Holt (ed.), Bergey's manual of systematic bacteriology, vol. 2. The Williams \& Wilkins Co., Baltimore.

9. Hao, M. V., M. Kocur, and K. Komagata. 1984. Marinococcus gen. nov., a new genus for motile cocci with meso-diaminopimelic acid in the cell wall; and Marinococcus albus sp. nov. and Marinococcus halophilus (Novitsky and Kushner) comb. 
nov. J. Gen. Appl. Microbiol. 30:449-459.

10. Harper, J. J., and G. H. G. Davis. 1979. Two-dimensional thin-layer chromatography for amino acid analysis of bacterial cell walls. Int. J. Syst. Bacteriol. 29:56-58.

11. Jones, D., and M. D. Collins. 1986. Section 15. Irregular, non-sporing Gram-positive rods, p. 1261-1434. In P. H. A. Sneath, N. S. Mair, M. E. Sharpe, and J. G. Holt (ed.), Bergey's manual of systematic bacteriology, vol. 2. The Williams \& Wilkins Co., Baltimore.

12. Kocur, M., and K. H. Schleifer. 1975. Taxonomic status of Micrococcus agilis Ali-Cohen 1889. Int. J. Syst. Bacteriol. 25:294-297.

13. Mesbah, M., U. Premachandran, and W. B. Whitman. 1989. Precise measurement of the $G+C$ content of deoxyribonucleic acid by high-performance liquid chromatography. Int. J. Syst. Bacteriol. 39:159-167.

14. Mikami, H., and Y. Ishida. 1983. Post-column fluorometric detection of reducing sugars in high-performance liquid chromatography using arginine. Bunseki Kagaku 32:E207-E210.

15. Minnikin, D. E., L. Alshamaony, and M. Goodfellow. 1975. Differentiation of Mycobacterium, Nocardia and related taxa by thin-layer chromatographic analysis of whole-organism methanolysates. J. Gen. Microbiol. 88:200-206.

16. Minnikin, D. E., M. D. Collins, and M. Goodfellow. 1979. Fatty acid and polar lipid composition in the classification of Cellulomonas, Oerskovia and related taxa. J. Appl. Bacteriol. 47:87-95.
17. Saito, H., and K. Miura. 1963. Preparation of transforming deoxyribonucleic acid by phenol treatment. Biochim. Biophys. Acta 72:619-629.

18. Schleifer, K. H. 1986. Family I. Micrococcaceae Prevot 1961, $31^{\text {AL }} 1986$, p. 1003-1035. In P. H. A. Sneath, N. S. Mair, M. E. Sharpe, and J. G. Holt (ed.), Bergey's manual of systematic bacteriology, vol. 2. The Williams \& Wilkins Co., Baltimore.

19. Schleifer, K. H., and O. Kandler. 1972. Peptidoglycan types of bacterial cell walls and their taxonomic implications. Bacteriol. Rev. 36:407-477.

20. Suzuki, K., and K. Komagata. 1983. Taxonomic significance of cellular fatty acid composition in some coryneform bacteria. Int. J. Syst. Bacteriol. 33:188-193.

21. Takeuchi, M., and A. Yokota. 1989. Cell-wall polysaccharides in coryneform bacteria. J. Gen. Appl. Microbiol. 35:233-252.

22. Uchida, K., and K. Aida. 1977. Acyl type of bacterial cell wall: its simple identification by colorimetric method. J. Gen. Appl. Microbiol. 23:249-260.

23. Ventosa, A., M. C. Marquez, F. Ruiz-Berraquero, and $M$. Kocur. 1990. Salinicoccus roseus gen. nov., sp. nov., a new moderately halophilic Gram-positive coccus. Syst. Appl. Microbiol. 13:29-33.

24. Wako Pure Chemical Industries, Ltd. 1989. Technical note for the system of PTC-amino acid analysis. Wako Pure Chemical Industries, Ltd., Osaka, Japan. (In Japanese.) 